\title{
Survey of reproduction management on Canadian dairy farms
}

\author{
J. Denis-Robichaud, ${ }^{*}$ R. L. A. Cerri,† A. Jones-Bitton, ${ }^{*}$ and S. J. LeBlanc* \\ *Department of Population Medicine, University of Guelph, Guelph, ON N1G 2W1, Canada \\ †Applied Animal Biology, Faculty of Land and Food Systems, University of British Columbia, Vancouver, BC V6T 1Z4, Canada
}

\section{ABSTRACT}

The objectives of this study were to (1) quantify current reproduction management practices, and (2) assess the association between these practices and herd reproductive performance on dairy farms in Canada. A bilingual survey was developed, validated, and administered from March to May 2014 to collect general and reproduction management and performance measures [annual 21-d pregnancy rate (PR), 21-d insemination rate (IR), and conception risk (CR)]. Associations between management practices and reproductive performance measures were tested using linear regression models. A total of 832 questionnaires were completed online and by mail, representing a response rate of $9 \%$. On average, farms had 77 lactating cows (median = $50)$ and 13 dry cows (median $=10)$, and Holstein was the most common breed ( $92 \%$ of herds). Lactating cow housing was tiestall on $61 \%$ of the farms, freestall on $37 \%$, and bedded pack on $2 \%$. The average voluntary waiting period was $58 \mathrm{~d}$ in milk (DIM). The main reproduction management practice per farm was defined as the means employed for $>50 \%$ of inseminations. Farms reported their main reproduction management practice for first and subsequent inseminations, respectively, as visual estrus detection (51 and $44 \%$ of herds), timed AI (21 and $23 \%$ of herds), automated activity monitoring (AAM; 10 and $10 \%$ of herds), other management practice (bulls; 2 and $2 \%$ of herds), and a combination of management practices (16 and $21 \%$ of herds). On farms using visual estrus detection, cows were observed for signs of estrus on average 3.5 times per day, for an average total of $36 \mathrm{~min} / \mathrm{d}$. The most common use of reproductive hormones was to synchronize ovulation using Ovsynch (58\% of the farms). Average PR, IR, and CR were 17.6, 44.1, and 40.5\%, respectively. In linear regression analyses adjusted for confounders, pregnancy rate was significantly associated with geographic region, housing (tiestall: $\mathrm{PR}=15.4 \%$, freestall: $\mathrm{PR}=$

\footnotetext{
Received May 11, 2016.

Accepted July 27, 2016.

${ }^{1}$ Corresponding author: sleblanc@uoguelph.ca
}

$17.6 \%)$, herd size ( $<50$ lactating cows: $\mathrm{PR}=16.2 \%$, 50-100 cows: $\mathrm{PR}=16.5 \%,>100$ cows: $\mathrm{PR}=17.8 \%)$, voluntary waiting period $(\leq 60 \mathrm{DIM}: \mathrm{PR}=17.6 \%,>60$ DIM: $\mathrm{PR}=15.9 \%$ ), and frequency of insemination per day (once daily: $\mathrm{PR}=16.6 \%$, twice or more daily: $\mathrm{PR}$ $=18.1 \%)$. The main reproduction management practice at first and subsequent inseminations was divergently associated with IR and CR, but not with $\mathrm{PR}$ (visual heat detection: $\mathrm{PR}=17.4 \%$, timed $\mathrm{AI}: \mathrm{PR}=18.4 \%$, AAM: $\mathrm{PR}=17.1 \%$, combined practices: $\mathrm{PR}=18.2 \%$ ). Key words: reproduction management, reproductive performance, survey, Canada

\section{INTRODUCTION}

Reproductive performance is highly variable among dairy herds in North America (LeBlanc, 2005; Ferguson and Skidmore, 2013), as are general and reproduction management practices (Caraviello et al., 2006b). Traditionally, visual observation of cows' behavior has been the main approach for identifying cows in estrus, but the limits and challenges of this practice have been known for decades (Foote, 1975; Senger, 1994; Van Eerdenburg et al., 1996) and include shorter and less intense estrus episodes and decreased labor on dairy farms. Various management tools and technologies are available to producers, and randomized clinical trials have shown comparable herd reproductive performance with different programs for synchronization of ovulation and timed AI or with automated activity monitoring (AAM) systems (Neves et al., 2012; Fricke et al., 2014). Although randomized controlled trials are very useful, they do not reflect the complex reality of variable performance among commercial farms or over time within a farm because of other variables including management practices, nutrition, heat stress, work-force availability and skills, or compliance with a program (Neves et al., 2012; Dolecheck et al., 2016).

Although a good body of experimental evidence exists on various reproductive management programs, few data are available on how, and how widely, various techniques and tools are implemented on Canadian farms and how management affects reproductive 
performance. Studies on large commercial farms in the United States showed that a combination of visual estrus detection and timed AI was used in most (>90\%) herds, and aids to visual heat detection such as tail chalk were reported to be used in more than half of the herds, while pedometers were used in only 8 to 13\% (Caraviello et al., 2006b; Ferguson and Skidmore, 2013). Management characteristics such as the length of the voluntary waiting period (VWP), accuracy of timing of insemination, stocking density, housing, insemination technique, and use of a resynchronization program were identified as explanatory variables for reproductive performance (Caraviello et al., 2006a; Schefers et al., 2010). Ferguson and Skidmore (2013) suggested that reproductive management that results in higher insemination rate was associated with excellent reproductive performance, yet the approach to reproductive management (e.g., visual heat detection, timed AI, or AAM) was not identified as a major explanatory variable for reproductive performance in other studies (Caraviello et al., 2006a; Schefers et al., 2010).

Without strong evidence on which reproductive management practices perform the best, it would be useful to identify associations of herd variables or programs with reproductive performance, and identify possible interactions of herd variables with chosen practices. Therefore, the first objective of the present study was to quantify current reproduction management practices in a representative sample of Canadian dairy farms. The second objective was to assess the association between reproduction management practices and herd reproductive performance. The hypothesis was that different reproduction management practices would be associated with different measures of reproductive performance.

\section{MATERIALS AND METHODS}

\section{Experimental Design}

A survey study was developed to collect general and reproduction management information on dairy herds across Canada. This study was evaluated and approved by the University of Guelph Research Ethics Board (no. 14JA048). To survey farms nationally, a quantitative questionnaire was created in English then translated to French and validated with pilot groups and backtranslation techniques (Scholl et al., 1992; Dufour et al., 2010). Briefly, 3 experts in dairy reproduction drafted the questionnaire and chose the most pertinent questions $(\mathrm{n}=99)$. Questions were then translated from English to French by the first author. These questions were then translated back to English by a bilingual collaborator that had not previously read the question- naire. The 2 English versions were then compared to identify potential errors or inadequate translations. To have closer meanings in both languages, 5 modifications of the content and sentence structure were made in the English questionnaire and 2 in the French version. Twenty herd managers (10 English-speaking and 10 French-speaking) were contacted and asked to answer the questionnaire online. They were then contacted by phone to evaluate the clarity of the questions and the length of the response process. No changes were necessary for the clarity of the questions, but 29 questions were removed to reduce the duration to approximately $30 \mathrm{~min}$. The full questionnaire is available (Supplemental Data File S1; http://dx.doi.org/10.3168/jds.201611445).

From March to May 2014, the questionnaire was administered to Canadian dairy farmers by internet (FluidSurveys, Ottawa, ON, Canada) and mail. A web link to the questionnaire was sent to all available email addresses of subscribers to the milk recording (DHIA) services in Canada: CanWest DHI (Guelph, ON, Canada) and Valacta (Sainte-Anne-de-Bellevue, QC, Canada), representing a total of approximately 3,000 dairy farms. A printed advertisement card with the web address and a QR code link was distributed through milk recording services communications to reach farmers for whom we did not have an email address (in The Milk Producer magazine for CanWest DHI members and the monthly report for Valacta members), reaching approximately 8,000 dairy farmers in total. To maximize reach, a paper copy of the questionnaire was sent to 2,000 randomly selected milk recording subscribers with their monthly DHIA report (1,000 CanWest DHI and 1,000 Valacta members). Some overlap was expected in the population reached via different methods of communication, and we estimated the total population contacted to be nearly 9,000 dairy herds. At that time, there were 11,962 dairy herds in Canada (Canadian Dairy Information Center, 2014). To increase the response rate, we offered an estimate of completion time, emphasized the objective of the study, and provided a financial incentive for completion (entry in a drawing to win $\$ 250$; Dillman et al., 2008; Dohoo et al., 2009).

The respondents were allowed to leave any question unanswered. The questionnaire had a total of 70 questions about demographic information, farm characteristics, general management practices, transition management, and reproduction management. Questions on opinions and attitudes toward reproduction were also asked but will be reported in a separate paper. In the section for reproduction management, respondents were asked to give the proportion of inseminations that were based on visual estrus detection, timed AI, AAM, or other means. When the choice "other" was selected, 
respondents were asked to specify their answer. Herds were then classified according to their main reproduction management practice, which was defined as the practice used for more than $50 \%$ of the inseminations in lactating cows. If a single management practice did not account for more than $50 \%$ of the inseminations, herds were classified as using a combination of management practices. Herd size was categorized as $<50$ lactating cows, 50 to 100 lactating cows, and >100 lactating cows, to roughly balance categories based on the distribution of the Canadian herd size $(<50$ cows: $29 \%$ of the herds, 50-100 cows: $41 \%$ of the herds, and $>100$ cows: $30 \%$ of the herds). The reported VWP for AI was classified using the median ( $\leq 60$ DIM or $>60$ DIM).

Online answers were downloaded into Microsoft Excel (Microsoft Corp., Richmond, WA) spreadsheets and the data entry for mailed answers was done with Microsoft Access (Microsoft Corp.). All data were collated in Microsoft Excel.

Respondents were asked to give one-time access to their data from milk recording services. If they gave permission and a valid herd identification number, data on AI and pregnancy dates were entered in DairyComp 305 (VAS, Tulare, CA). Annual 21-d pregnancy rate (PR), 21-d insemination rate (IR), and conception risk (CR; probability of diagnosed pregnancy per AI) for the year 2013 were extracted from the software using a standardized VWP of $50 \mathrm{~d}$ postpartum.

\section{Statistical Analysis}

Statistical analyses were conducted using SAS 9.3 (SAS Institute, Cary, NC). Means, medians, and interquartile ranges (IQR; 1st to 3rd quartile) were calculated for continuous and ordinal variables, and frequencies were calculated for binary and categorical variables. For descriptive purposes, some associations between categorical variables were tested using the chi-squared test for independence. The difference between PR, IR, and CR obtained from DHIA records and reported by the respondents were assessed graphically. The relative effect of IR and CR on PR was investigated using a linear regression model (PROC GLM). Associations between management practices and each reproductive performance measure (PR, IR, and $\mathrm{CR}$ ) were tested using linear regression models (PROC GLM). Confounders and intervening variables were identified with a causal diagram (Figure 1), and confounders were included in the models. Collinearity between predictors was assumed if 2 categorical variables were associated with an odds ratio $\geq 8$, or if a continuous and a categorical variable were significantly associated (ANOVA; Dohoo et al., 2009). When collinearity was present, only one

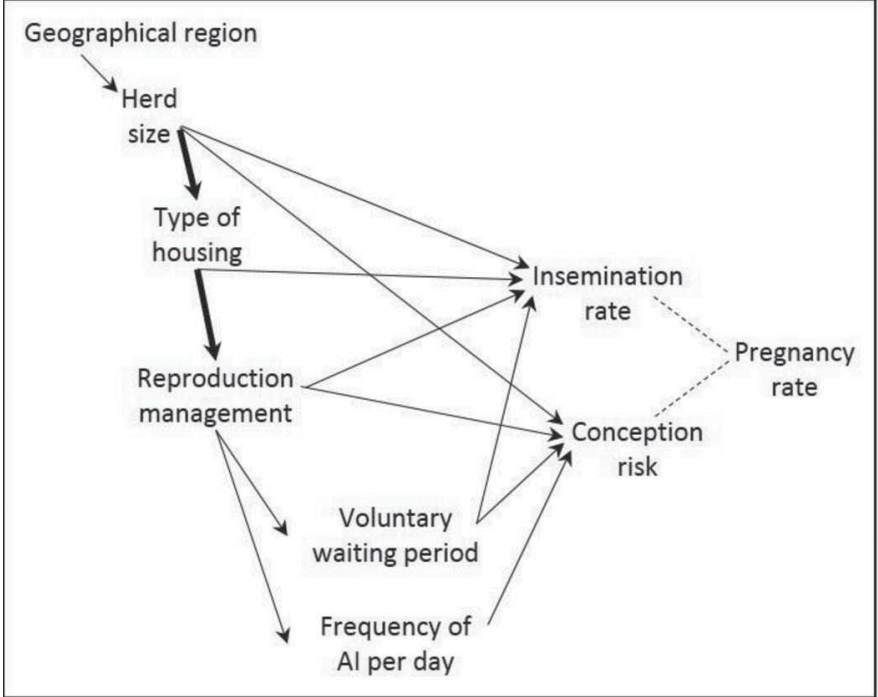

Figure 1. Partial causal diagram for measured variables associated with 21-d insemination rate, conception risk, and 21-d pregnancy rate. Thicker arrows represent highly collinear variables (odds ratio >8; Dohoo et al., 2009).

(the most biologically plausible) confounder was kept as a fixed effect in the models. Two-way interactions were tested and kept in the models if significant $(P$ value $<0.05)$. Normality and homoscedasticity of the residuals was assessed graphically using standardized residuals. Outliers (residuals and student residuals), extreme (leverage), and influential data (Cook's distance and DFFITS) were generated to assess the fit of the models. Characteristics of extreme values were identify to understand their effect on the models (Dohoo et al., 2009). Marginal means (least squares means \pm SE) were obtained for categorical variables using the Tukey-Kramer adjustment for multiple comparisons. Missing data were deleted from analyses (complete-case analysis; Pigott, 2001).

\section{RESULTS}

\section{Questionnaire}

A total of 490 and 342 questionnaires were completed online and by mail, respectively, for a total of 832 responses. Because we can only approximate how many dairy producers were reached by the contact strategy (9,000 dairy farms), the response rate was estimated to be approximately $9 \%$. The number of responses represents $7 \%$ of the total number of farms in 2014 in Canada (Canadian Dairy Information Center, 2014). Of the 832 respondents, $66 \%(\mathrm{n}=548)$ gave access to their DHIA files and could be linked to the DHIA database. The percentage of unanswered questions (missing data) 
Table 1. Proportion (\%) of surveyed farms and all Canadian farms (Canadian Dairy Information Center, 2014; CDIC) using tiestall, freestall, and bedded packs for housing lactating and dry cows

\begin{tabular}{lccc}
\hline & \multicolumn{2}{c}{$\begin{array}{c}\text { Proportion (no.) of surveyed } \\
\text { farms housing }\end{array}$} & $\begin{array}{c}\text { Proportion (no.) } \\
\text { of farms reported } \\
\text { by the CDIC in } 2014\end{array}$ \\
\cline { 2 - 3 } Barn type & Lactating cows & Dry cows & $72(6,264)$ \\
\hline Tiestall & $61(502)$ & $34(281)$ & $28(2,474)$ \\
Freestall & $37(302)$ & $26(210)$ & \\
Bedded pack & $2(22)$ & $40(328)$ & \\
\hline
\end{tabular}

ranged from a low of $0.7 \%$ for lactating cow housing to a high of $9 \%$ for access to pasture.

\section{Respondents}

Ninety-eight percent of the respondents reported being members of a milk recording service (CanWest DHI: $\mathrm{n}=452$; Valacta: $\mathrm{n}=359)$. The respondents were from 9 out of 10 Canadian provinces (Figure 2). The respondents' ages were under $30 \mathrm{yr}(20 \%, \mathrm{n}=164)$, between 30 and 39 yr $(27 \%, \mathrm{n}=220)$, between 40 and $49 \mathrm{yr}(23 \%, \mathrm{n}=193)$, between 50 and $59 \mathrm{yr}(26 \%, \mathrm{n}=$ $212)$, and $60 \mathrm{yr}$ and above $(4 \%, \mathrm{n}=33)$. Their highest completed level of education was high school for $31 \%$ $(\mathrm{n}=253)$, community college or diploma for $55 \%(\mathrm{n}=$ $446)$, undergraduate university for $13 \%(\mathrm{n}=107)$, and graduate university for $1 \%(\mathrm{n}=10)$. Seventy-five percent $(\mathrm{n}=615)$ of the respondents expected their farm to be in operation for more than $20 \mathrm{yr}$. The proportion of respondents who gave access to their milk recording data was higher for farms from British Columbia, Alberta, Saskatchewan, Québec, and Prince Edward Island than for other provinces $(P<0.01)$. Respondents between 30 and 49 yr old were more likely to give access to their milk recording data than other age groups $(P$ $<0.01$ ). The level of education was similar between those that did gave access to their herd's reproductive performance data and those that did not $(P=0.22)$.

\section{Farms}

Farms had, on average, 77 lactating cows (median $=$ $55, \mathrm{IQR}=40-88), 13$ dry cows $($ median $=10, \mathrm{IQR}=$ 6-15), and 72 replacement animals (newborn to first calving; median $=50, \mathrm{IQR}=34-85$ ), while the average Canadian dairy farm had 80 adult cows (lactating and dry; Canadian Dairy Information Center, 2014). Holstein was the most common breed $(92 \%, \mathrm{n}=770)$ followed by Ayrshire $(3 \%, \mathrm{n}=21)$, Jersey $(2 \%, \mathrm{n}=$ $18)$, and other breeds $(1 \%, \mathrm{n}=11)$. The proportion of farms that housed lactating and dry cows in tiestall, freestall, and bedded pack barns is presented in Table 1 , along with the proportions reported by the Canadian
Dairy Information Center (2014). The calving area was a tiestall on $29 \%(\mathrm{n}=237)$ of the farms, group bedded pack on $27 \%(\mathrm{n}=225)$, individual box stall on $41 \%(\mathrm{n}=338)$, and freestall on $3 \%(\mathrm{n}=23)$. The barns for lactating cows were built on average 31 years ago $($ median $=23, \mathrm{IQR}=10-43)$, and $14 \%(\mathrm{n}=114)$ of the farms had undergone major renovations in the lactating cow barn during the year preceding the questionnaire (2013). Tiestall barns were significantly older than freestall barns (built 40 and $17 \mathrm{yr}$ ago, respectively; $P<0.01$ ). All farm characteristics were similar in the group of respondents who gave access to their milk recording data and those who did not $(P>0.10)$.

\section{General Management}

Seventy-five percent $(\mathrm{n}=573)$ of the respondents did not provide pasture access to lactating cows, while $18 \%(\mathrm{n}=138)$ provided access to pasture both night and day, $4 \%(\mathrm{n}=31)$ at night only, and $2 \%(\mathrm{n}=18)$ during the day only, during the warm season. Cows in

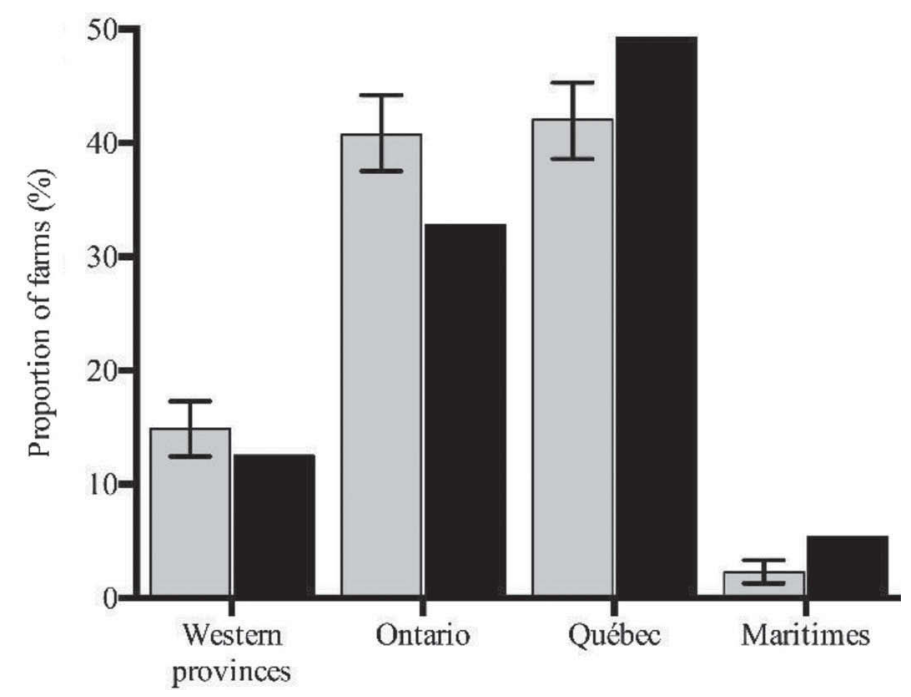

Figure 2. Proportion of respondents (gray; with 95\% CI) and of Canadian farms (black; Canadian Dairy Information Center, 2014) from western provinces $(\mathrm{n}=123)$, Ontario $(\mathrm{n}=336)$, Québec $(\mathrm{n}=$ $347)$, and Maritimes $(\mathrm{n}=19)$. 
Table 2. Proportion of farms (\%; no. in parentheses) using different main reproduction management practices (for $>50 \%$ of the inseminations in lactating cows) in tiestall barns and freestall or bedded pack barns for first ( $\mathrm{n}=810$ farms) and subsequent $(\mathrm{n}=800$ farms) inseminations

\begin{tabular}{|c|c|c|c|c|c|c|}
\hline \multirow[b]{2}{*}{$\begin{array}{l}\text { Main reproduction management } \\
\text { practice }\end{array}$} & \multicolumn{3}{|c|}{ First inseminations } & \multicolumn{3}{|c|}{ Subsequent inseminations } \\
\hline & Tiestall & $\begin{array}{l}\text { Freestall or } \\
\text { bedded pack }\end{array}$ & $P$-value & Tiestall & $\begin{array}{l}\text { Freestall or } \\
\text { bedded pack }\end{array}$ & $P$-value \\
\hline Visual estrus detection & $56.8(280)$ & $41.0(130)$ & $<0.01$ & $50.6(246)$ & $34.4(108)$ & $<0.01$ \\
\hline Timed AI & $27.6(136)$ & $12.0(38)$ & $<0.01$ & $27.4(133)$ & $15.0(47)$ & $<0.01$ \\
\hline Automated activity monitoring & $1.0(5)$ & $24.9(79)$ & $<0.01$ & $1.0(5)$ & $24.8(78)$ & $<0.01$ \\
\hline Other & $1.0(5)$ & $1.6(5)$ & 0.48 & $1.4(7)$ & $1.9(6)$ & 0.61 \\
\hline
\end{tabular}

tiestall barns were given access to pasture more often than cows in freestall barns (30 vs. $16 \% ; P<0.01$ ) and pasture access during the warm season differed among regions (western provinces: $15 \%$, Ontario: $31 \%$, Québec: 20\%, Maritimes: $50 \%$; $P<0.01$ ). A total of 20 farms $(2.3 \%)$ were reported to be organic and consisted of both tiestall and freestall barns (2.2 and 2.5\%, respectively, $P=0.79$ ).

\section{Transition Management}

The respondents used an average planned dry period of $57 \mathrm{~d}$ (median $=60, \mathrm{IQR}=55-60)$. Before calving, farms that had a calving area $(72 \%, \mathrm{n}=593)$ moved their cows at the first sign of calving $(8 \%, \mathrm{n}=69)$, the day before expected calving $(13 \%, \mathrm{n}=110), 1$ or $2 \mathrm{~d}$ before expected calving $(8 \%, \mathrm{n}=66)$, or $3 \mathrm{~d}$ or more before expected calving $(42 \%, \mathrm{n}=348)$. After calving, the reported VWP was $58 \mathrm{~d}$ on average $($ median $=60$, $\mathrm{IQR}=50-60)$. The VWP for heifers was 14 mo of age on average $($ median $=14, \mathrm{IQR}=13-15)$.

\section{Reproduction Management}

For lactating cows, $89 \%(\mathrm{n}=740)$ of the respondents used visual estrus detection, but only $8 \%(\mathrm{n}=70)$ used visual estrus detection for more than $90 \%$ of the inseminations on their farm, and $9 \%(\mathrm{n}=73)$ used visual estrus detection for less than $10 \%$ of the inseminations on their farm. Eighty-one percent $(\mathrm{n}=676)$ used timed AI ( $>90 \%$ timed AI: $2 \%, \mathrm{n}=15 ;<10 \%$ timed AI: $19 \%, \mathrm{n}=159), 23 \%(\mathrm{n}=193,89 \%$ freestall barns $)$ used an AAM system [ $>90 \%$ of AI based on the AAM system: $1 \%, \mathrm{n}=9$ (89\% freestall barns); $<10 \%$ AAM system: $77 \%, \mathrm{n}=638$ (25\% freestall barns)], and $7 \%$ $(\mathrm{n}=61)$ used other means as management practices to inseminate their cows. The use of AAM system was more frequent in freestall $(52 \%, \mathrm{n}=169)$ than in tiestall barns $(7 \%, \mathrm{n}=33)$. When specified $(\mathrm{n}=18)$, the category "other" was defined as the use of bulls. When asked in a separate question, the proportion of herds using clean-up bulls was higher $(17.8 \%, \mathrm{n}=$
148) than herds reporting using another management practice $(7 \%, \mathrm{n}=61)$. For first insemination, the main reproduction management practice $(>50 \%$ of first inseminations) was visual estrus detection ( $51 \%$ of farm, $\mathrm{n}=414)$, timed AI $(21 \%, \mathrm{n}=175), \operatorname{AAM}(10 \%, \mathrm{n}=$ $84)$, other practices $(1 \%, \mathrm{n}=10)$, and a combination of management practices $(16 \%, \mathrm{n}=132)$. For subsequent (second and greater) inseminations, the main reproduction management practice was visual estrus detection (44\% of farms, $\mathrm{n}=356)$, timed AI $(23 \%, \mathrm{n}=181)$, $\operatorname{AAM}(10 \%, \mathrm{n}=83)$, other practices $(2 \%, \mathrm{n}=14)$, and a combination of management practices $(21 \%, \mathrm{n}=$ 170). The distribution of main reproduction management practices was different in tiestall barns and in freestall or bedded pack barns, for first and subsequent inseminations (Table 2). The proportion of farms using a combination of management practices was lower for first inseminations compared with subsequent inseminations (44 vs. $56 \% ; P=0.01$ ), and the proportion of farms using visual estrus detection was higher for first inseminations compared with subsequent inseminations (54 vs. $46 \% ; P=0.01$ ).

For first and subsequent inseminations, the main reproduction management practices for heifers was visual heat detection in most herds $(69 \%, \mathrm{n}=551)$. Timed AI $(7 \%, \mathrm{n}=55)$, AAM $(9 \%, \mathrm{n}=69)$, other practices $(7 \%$, $\mathrm{n}=52)$, and a combination of management practices $(9 \%, \mathrm{n}=68)$ were used in some herds.

On farms that used visual estrus detection, respondents observed cows for signs of estrus on average 3.5 times per day (median $=3$, IQR $=2-4$ ), for an average total of $36 \mathrm{~min} / \mathrm{d}($ median $=20, \mathrm{IQR}=10-35)$. The amount of time spent observing cows for signs of estrus was different if observation was the only task performed or if other tasks were done concurrently with estrus detection (22 and $41 \mathrm{~min}$, respectively, $P<0.01$ ). Aids to visual heat detection such as mount detectors and tail chalk or paint were used in only $7 \%(\mathrm{n}=62)$ and $5 \%(\mathrm{n}=39)$ of the herds, respectively.

Reproductive hormones were used for at least some of the inseminations on $84 \%$ of the farms $(n=692)$. Respondents could indicate that they used more than 
one hormonal intervention program. In lactating cows, hormones were used to synchronize estrus (47\% of farms, $\mathrm{n}=384$ ), synchronize ovulation using Ovsynch only $(58 \%, \mathrm{n}=472)$, synchronize ovulation using Ovsynch combined with a progesterone implant $(16 \%$, $\mathrm{n}=129$ ), or synchronize ovulation using presynchronization (e.g., Presynch or Double Ovsynch) followed by Ovsynch (21\%, $\mathrm{n}=171)$. More respondents housing cows in tiestall barns than in freestall barns reported using programs to synchronize ovulation (Ovsynch only: 61 vs. $50 \%, P<0.01$; Ovsynch and progesterone: 20 vs. $9 \%, P<0.01$; presynchronization and Ovsynch: 23 vs. $18 \%, P=0.09$ ), but not to synchronize estrus (46 vs. $47 \%, P=0.73$ ). For heifers, hormones were used to synchronize estrus ( $37 \%$ of farms, $\mathrm{n}=307$ ), synchronize ovulation using Ovsynch only $(16 \%, \mathrm{n}=$ 133), synchronize ovulation using Ovsynch combined with a progesterone implant $(3 \%, \mathrm{n}=24)$, or synchronize ovulation using presynchronization (e.g., Presynch or Double Ovsynch) followed by Ovsynch $(2 \%, \mathrm{n}=15)$. Region and herd size were not independently associated with the use of timed AI programs.

On farms using an AAM system, the respondents reported consulting the system for estrus alarms once per day $(9 \%, \mathrm{n}=16)$, twice per day $(60 \%, \mathrm{n}=105)$, or more than twice per day $(31 \%, \mathrm{n}=54)$. Eighty-three percent confirmed an alarm with observation of signs of estrus before inseminating (all the time: $\mathrm{n}=52$; more than $50 \%$ of the time: $\mathrm{n}=59 ; 50 \%$ of the time or less: $\mathrm{n}$ $=37)$. The majority of respondents reported that they inseminated cows not identified by the AAM system less than $10 \%$ of the time $(59 \%, \mathrm{n}=105)$. An equal proportion of the remaining respondents inseminated cows not identified in estrus by the AAM system 10 to $20 \%$ of the time $(20 \%, \mathrm{n}=36)$ or more than $20 \%$ of the time $(21 \%, \mathrm{n}=38)$. Rumination detection was reported to be used on $5 \%(\mathrm{n}=43)$ of the farms.

For lactating cows, inseminations were performed once $(52 \%, \mathrm{n}=406)$, twice $(41 \%, \mathrm{n}=321)$, or more than twice $(7 \%, \mathrm{n}=52)$ per day, whereas they were performed once $(59 \%, \mathrm{n}=432)$, twice $(36 \%, \mathrm{n}=263)$, or more than twice $(5 \%, \mathrm{n}=35)$ per day for heifers. The primary inseminator on farm was the owner $(46 \%$, $\mathrm{n}=368)$, an artificial insemination company $(45 \%, \mathrm{n}=$ $360)$, or an employee $(9 \%, \mathrm{n}=70)$. Eighteen percent of respondent farms $(\mathrm{n}=147)$ had more than one person doing the inseminations.

Thirty-four percent $(\mathrm{n}=279)$ of herds diagnosed pregnancies starting before $30 \mathrm{~d}$ post insemination, while $9 \%(\mathrm{n}=73)$ diagnosed pregnancies no sooner than $45 \mathrm{~d}$ post insemination. Thirty-two percent (n $=265)$ of herds did not routinely confirm pregnancy, $24 \%(\mathrm{n}=194)$ confirmed initial pregnancy diagnosis before $60 \mathrm{~d}$ postinsemination, $33 \%(\mathrm{n}=270)$ confirmed between 60 and 80 d postinsemination, and $11 \%$ (n $=90$ ) after $80 \mathrm{~d}$ postinsemination. The veterinarian was scheduled for a routine herd health visit including pregnancy diagnosis weekly $(3 \%, \mathrm{n}=26)$, every 2 to 3 weeks $(41 \%, \mathrm{n}=336)$, monthly $(40 \%, \mathrm{n}=329)$, or less than once a month $(16 \%, \mathrm{n}=130)$.

\section{Reproductive Performance}

The difference between reproductive performance indices obtained from DHIA and reported by the respondents are shown in Figure 3. The range of the differences is wide; however, $54 \%$ of the respondents reported a PR within $\pm 5 \%$ points of their actual PR as reported by DHIA, $35 \%$ of respondents reported an IR $\pm 5 \%$ points of their actual IR, and $49 \%$ of respondents reported a $\mathrm{CR} \pm 5 \%$ points of their actual $\mathrm{CR}$. The distribution of the annual PR, IR, and CR obtained from DHIA for 2013 are presented in Figure 4. The average $\mathrm{PR}$ was $17.6 \%(\mathrm{SD}=5.4$, median $=17, \mathrm{IQR}$ $=14-21), \mathrm{IR} 44.1 \%(\mathrm{SD}=11.6$, median $=45, \mathrm{IQR}=$ $37-52)$, and $\mathrm{CR} 40.5 \%(\mathrm{SD}=8.9$, median $=40$, IQR $=35-46)$. Scatter plots of the relationship between PR and IR and CR are displayed in Figure 5. The relationship between IR and PR $\left(\mathrm{R}^{2}=0.525\right)$ was stronger than that between $\mathrm{CR}$ and $\mathrm{PR}\left(\mathrm{R}^{2}=0.157\right)$.

Variables such as region, housing, herd size, VWP, number of insemination per day, main reproduction management practices, and use of presynchronization followed by Ovsynch for first inseminations and subsequent (not shown) inseminations were associated with PR (Table 3), IR (Table 4), or CR (Table 5) in multivariable analyses. The categories for which PR was higher also had higher IR (i.e., Québec province, freestall housing, herd size $>100$ lactating cows, reported VWP $\leq 60$ DIM, frequency of insemination twice per day or more). Herds with visual estrus detection as the main practice had lower IR than herds with timed AI or combined practices but higher CR than herds mainly using timed AI (Tables 3, 4, and 5). In the models for PR, IR, and CR, only 3,1 , and 6 outliers were identified, respectively. The outliers were kept in the models because removing them did not affect the direction or the magnitude of the coefficients.

\section{DISCUSSION}

As expected, management practices varied considerably among Canadian dairy farms surveyed. Visual estrus detection was still used on most farms to various extents, but alternative practices such as timed AI and AAM were also implemented on many farms. These alternatives to observation for estrus detection seemed to be more for subsequent inseminations than first in- 


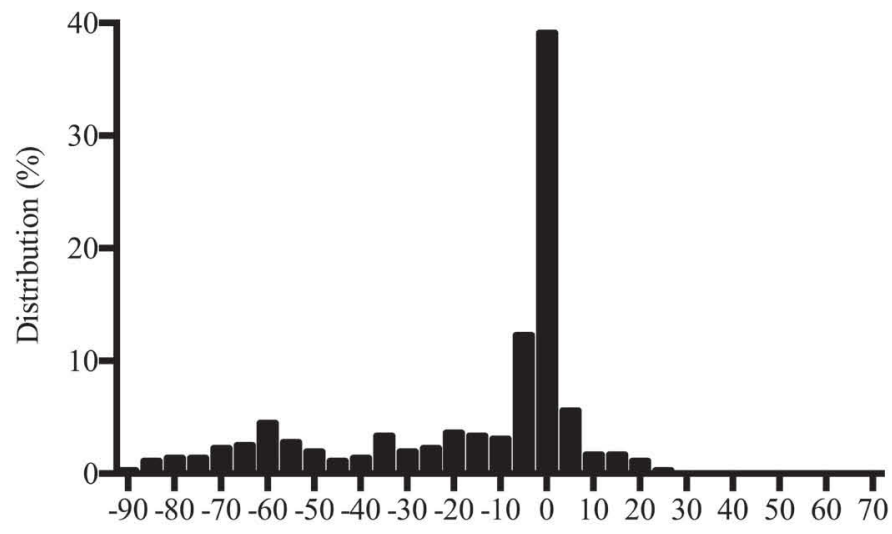

Difference PR (DHIA) - reported PR

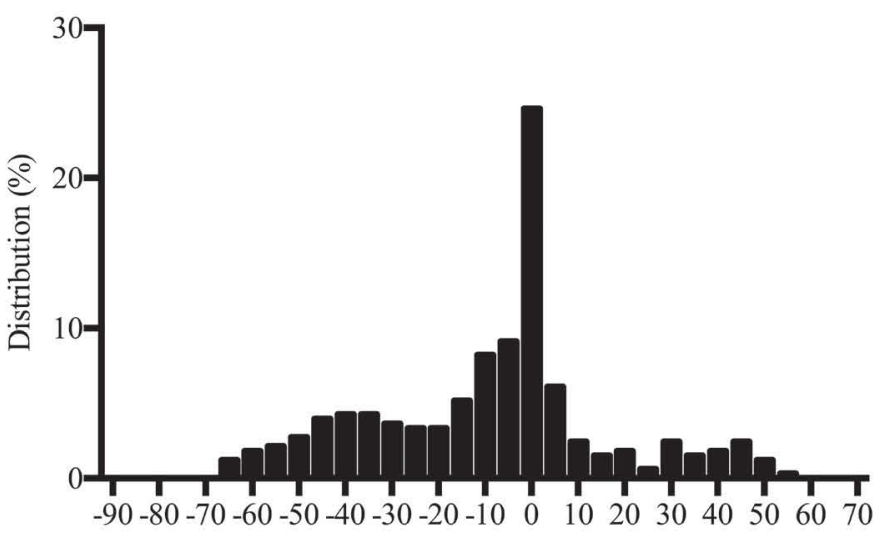

Difference IR (DHIA) - reported IR

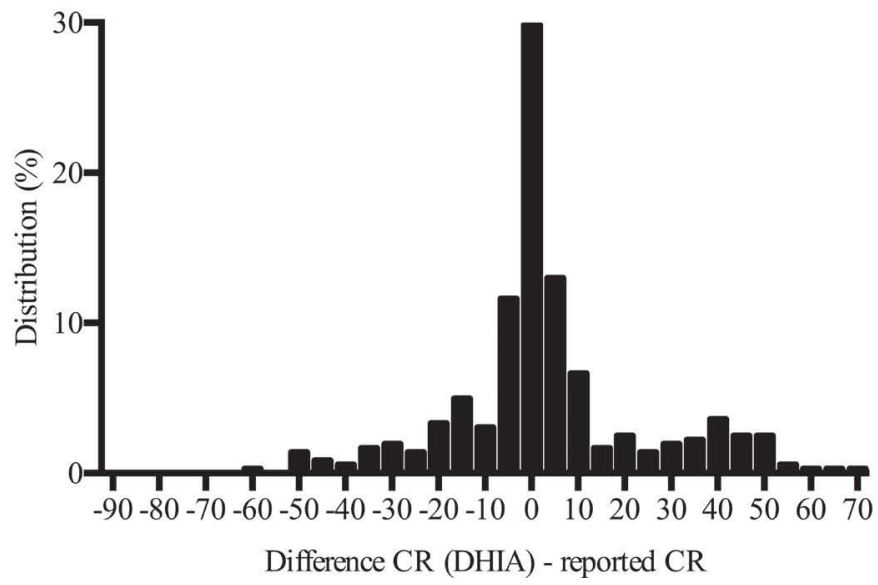

Figure 3. Distribution of the difference between reproductive performance obtained from DHIA [21-d pregnancy rate (PR), 21-d insemination rate (IR), and conception risk (CR)], and those reported by the respondent from 358 Canadian herds in 2013. The average difference for $\mathrm{PR}$ was $16.4 \%[\mathrm{SD}=25.9$, median $=3$, interquartile range $(\mathrm{IQR})$ $=0-31], 8.6 \%$ for IR $(\mathrm{SD}=25.6$, median $=4, \mathrm{IQR}=-2$ to 25$)$, and -3.0 for $\mathrm{CR}(\mathrm{SD}=20.9$, median $=-1, \mathrm{IQR}=-8$ to 4$)$.
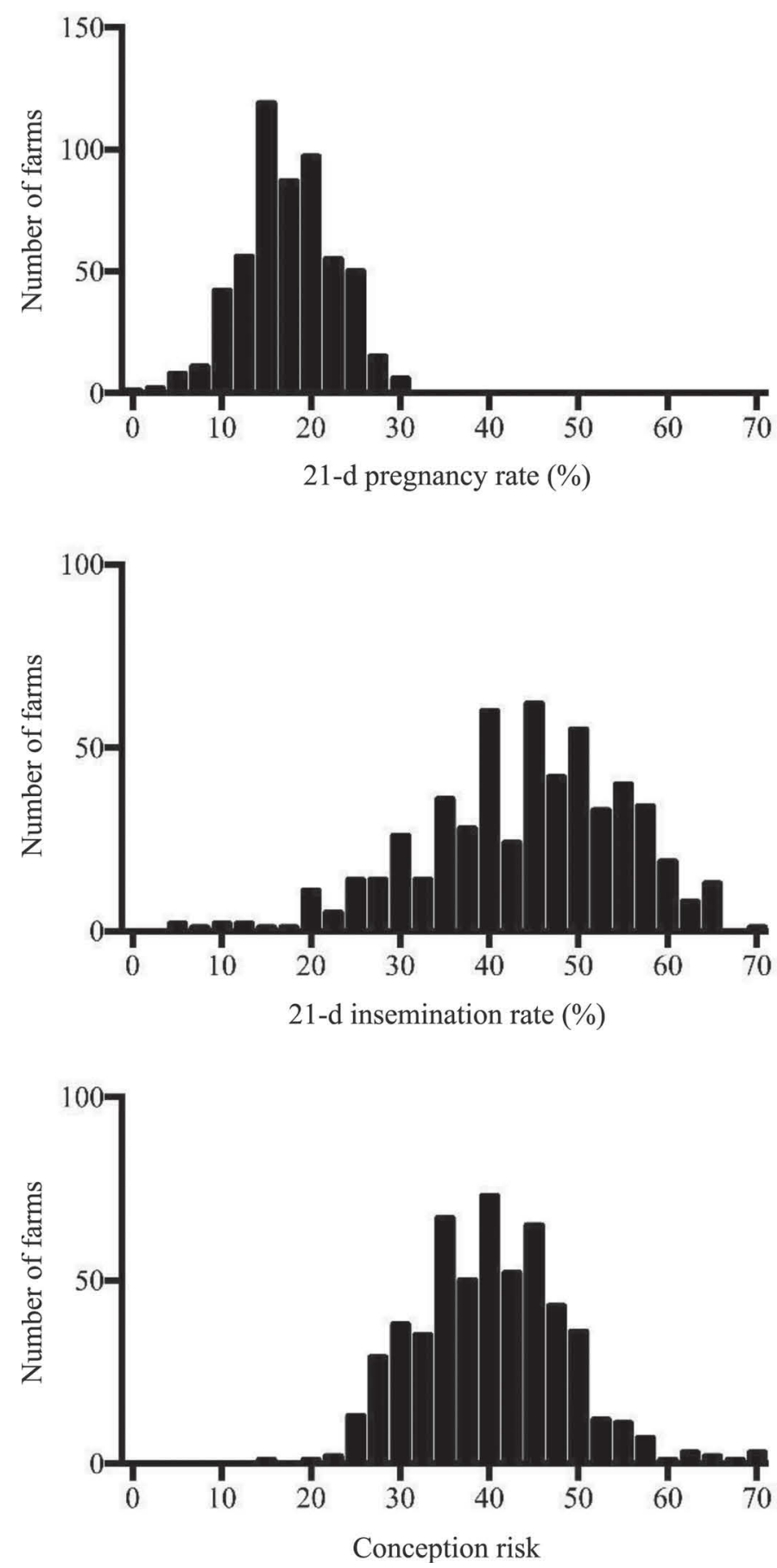

Figure 4. Distribution of annual 21-d pregnancy rate (PR), 21-d insemination rate (IR), and conception risk (CR) for lactating cows, using a standard voluntary waiting period of 50 DIM, calculated with Dairy Comp 305 (VAS, Tulare, CA) from 542 Canadian herds in 2013. The average $\mathrm{PR}$ was $17.6 \%[\mathrm{SD}=5.4$, median $=17$, interquartile range $(\mathrm{IQR})=14-21], \mathrm{IR} 44.1 \%(\mathrm{SD}=11.6$, median $=45, \mathrm{IQR}=$ $37-52)$, and $\mathrm{CR} 40.5 \%(\mathrm{SD}=8.9$, median $=40, \mathrm{IQR}=35-46)$. 
seminations; the proportion of respondents using visual estrus detection as their main reproduction management for first inseminations decreased for subsequent inseminations to the benefit of combined practices.

Assessing the representativeness of our sample of respondents, we found that the distribution of the farms throughout the provinces (Figure 2), the average number of cows per farm, and the proportion of freestall and tiestall barns were slightly different from the population of Canadian farms in 2014 (Canadian Dairy Information Center, 2014). These discrepancies can be explained by the fact that advertisement was done differently by CanWest DHI in the western provinces and Valacta in the eastern provinces, which resulted in more responses from the western provinces, where more farms have freestall barns and herd sizes are larger (Canadian Dairy Information Center, 2014). This circumstance might also have inflated the apparent proportion of farms using AAM systems (Neves and
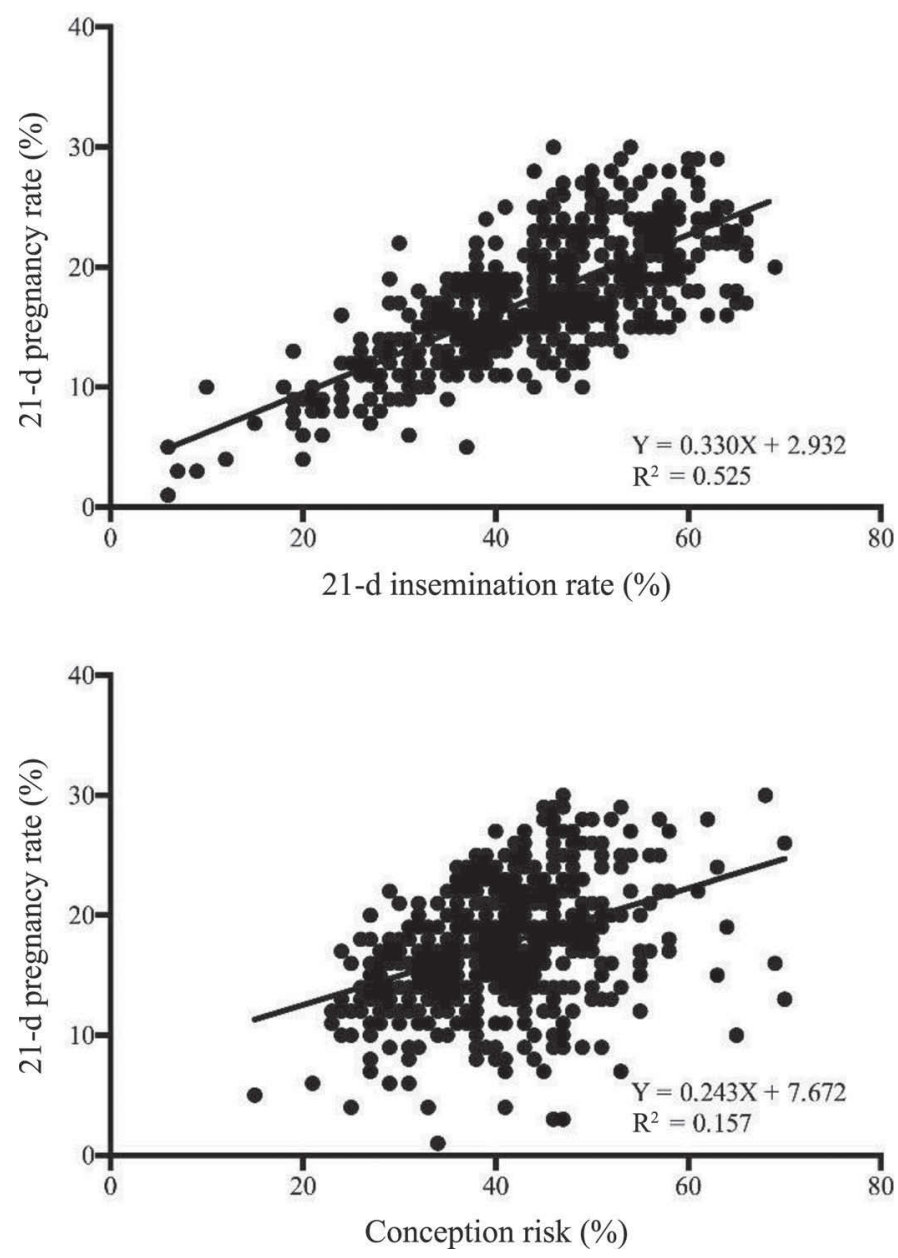

Figure 5. Scatter plot of annual 21-d pregnancy rate against 21-d insemination rate and conception risk in 542 Canadian dairy herds in 2013.

Journal of Dairy Science Vol. 99 No. 11, 2016
LeBlanc, 2015). Despite voluntary response to the questionnaire and the slight differences between the sample and the target population, we think that the present results provide a good representation of the diversity of management approaches on Canadian dairy farms.

Regarding comparability with other studies, reproduction management practices have not been described for a representative sample of herds in the United States, although data exist for large commercial farms (Caraviello et al., 2006b). Even though the surveyed population in the US study was different than the present study (only freestall barns, larger herds), it is interesting to observe greater use of AAM systems in freestall barns (Caraviello et al., 2006b: 8\%, our data for 2014: $52 \%$ ), and less time dedicated to visual estrus detection (Caraviello et al., 2006b: 2.8 times per day, 27 min per observation bout; our data for 2014: 3.5 times per day for a total of $36 \mathrm{~min}$ ), yet the similar proportion of herds using reproductive hormones to some extent (Caraviello et al., 2006b: 87\%; our data for 2014: $81 \%$ ). The target population for the present study was all Canadian dairy farms and was reached via mail or internet, while Caraviello et al. (2006b) had very specific criteria to select their sample and conducted live interviews, which might explain the difference in time for visual heat detection. The difference in use of AAM system is more likely to be due to the rapid increase in commercialization of AAM systems in the last 5 years. In the present study, it was possible to estimate the approximate proportion of inseminations done following the use of timed AI. Even though the proportion of farms using timed AI was similar between the 2 studies, the extent of use likely differed between the 2 samples.

To our knowledge, this study is the most complete report of reproductive performance on Canadian dairy farms. Reproductive performance data were only obtained for members of a milk recording service who gave voluntary access to their data, which might have given higher PR, IR, and CR than the source population. Other recent studies obtained very similar (Neves and LeBlanc, 2015) or better (elite herds; Ferguson and Skidmore, 2013) reproductive performance, but a previous Canadian (LeBlanc, 2005) report had lower measures of performance $(\mathrm{PR}=13 \%, \mathrm{IR}=33 \%, \mathrm{CR}=$ $38 \%$ ). Even though the sample from the latter study is not the same as here, these data suggest that reproductive performance is at least stable, if not improving in Canada, which was also suggested by Norman et al. (2009) in the United States. The apparent increase of IR over time, and consequently of PR, is likely the consequence of increased use of estrus detection technologies (i.e., AAM) and synchronization programs (combined practices and timed AI, Table 2). This explanation is supported by the stronger correlation between PR and 
Table 3. Linear regression models and marginal means (adjusted for multiple comparisons; Tukey-Kramer) presenting associations between herd characteristics and management practices, and annual 21-d pregnancy rate $(\mathrm{PR})$ adjusted for confounders

\begin{tabular}{|c|c|c|c|c|}
\hline Dependent variable & No. & $\begin{array}{l}\text { Coefficient } \\
\quad( \pm \mathrm{SE})\end{array}$ & $P$-value & $\begin{array}{l}\mathrm{PR} \% \\
( \pm \mathrm{SE})\end{array}$ \\
\hline \multicolumn{5}{|l|}{ Model 1} \\
\hline Intercept & & $17.0( \pm 0.6)$ & $<0.01$ & \\
\hline \multicolumn{5}{|l|}{ Geographical region } \\
\hline Western provinces & 81 & Referent & & $17.0^{\mathrm{a}}( \pm 0.6)$ \\
\hline Ontario & 206 & $-0.3( \pm 0.7)$ & & $16.7^{\mathrm{a}}( \pm 0.4)$ \\
\hline Québec & 249 & $1.5( \pm 0.7)$ & & $18.5^{\mathrm{b}}( \pm 0.3)$ \\
\hline Maritimes & 12 & $0.0( \pm 1.7)$ & $<0.01$ & $17.0^{\mathrm{ab}}( \pm 1.5)$ \\
\hline \multicolumn{5}{|l|}{ Model 2} \\
\hline Intercept & & $15.8( \pm 0.8)$ & $<0.01$ & \\
\hline \multicolumn{5}{|l|}{ Herd size $^{1}$} \\
\hline$<50$ lactating cows & 211 & Referent & & $16.6^{\mathrm{a}}( \pm 0.6)$ \\
\hline 50-100 lactating cows & 221 & $0.56( \pm 0.5)$ & & $17.2^{\mathrm{ab}}( \pm 0.5)$ \\
\hline$>100$ lactating cows & 112 & $1.8( \pm 0.7)$ & 0.02 & $18.4^{\mathrm{b}}( \pm 0.6)$ \\
\hline \multicolumn{5}{|l|}{ Model 3} \\
\hline \multirow{2}{*}{\multicolumn{5}{|c|}{ Type of housing ${ }^{1,2}$}} \\
\hline & & & & \\
\hline Freestall barn or bedded pack & 210 & Referent & & $18.3^{\mathrm{a}}( \pm 0.5)$ \\
\hline Tiestall barn & 337 & $-2.1( \pm 0.5)$ & $<0.01$ & $16.2^{\mathrm{b}}( \pm 0.5)$ \\
\hline \multicolumn{5}{|l|}{ Model 4} \\
\hline Intercept & & $14.4( \pm 0.8)$ & $<0.01$ & \\
\hline \multicolumn{5}{|l|}{ Main reproduction management at first $\mathrm{AI}^{1,3}$} \\
\hline Visual estrus detection & 275 & Referent & & $16.8( \pm 0.5)$ \\
\hline Timed AI & 123 & $1.1( \pm 0.6)$ & & $17.9( \pm 0.6)$ \\
\hline Automated activity monitoring & 52 & $0.0( \pm 0.9)$ & & $16.8( \pm 0.9)$ \\
\hline Other & 2 & $-1.0( \pm 3.8)$ & & $15.9( \pm 3.8)$ \\
\hline Combination of practices & 83 & $0.9( \pm 0.7)$ & 0.34 & $17.7( \pm 0.7)$ \\
\hline \multicolumn{5}{|l|}{ Model 5} \\
\hline Intercept & & $15.6( \pm 1.0)$ & $<0.01$ & \\
\hline \multicolumn{5}{|l|}{ Use of presynchronization ${ }^{1,3,4}$} \\
\hline No & 450 & Referent & & $16.8^{\mathrm{a}}( \pm 0.9)$ \\
\hline Yes & 99 & $1.3( \pm 0.7)$ & 0.05 & $18.1^{\mathrm{b}}( \pm 1.0)$ \\
\hline \multicolumn{5}{|l|}{ Model 6} \\
\hline Intercept & & $14.6( \pm 0.8)$ & $<0.01$ & \\
\hline \multicolumn{5}{|l|}{ Reported voluntary period ${ }^{1,2,4}$} \\
\hline$\leq 60$ DIM & 418 & Referent & & $17.4^{\mathrm{a}}( \pm 0.9)$ \\
\hline$>60 \mathrm{DIM}$ & 130 & $-1.7( \pm 0.5)$ & $<0.01$ & $15.8^{\mathrm{b}}( \pm 1.0)$ \\
\hline \multicolumn{5}{|l|}{ Model 7} \\
\hline \multirow{2}{*}{\multicolumn{5}{|c|}{$\begin{array}{l}\text { Intercept } \\
\text { Frequency of AI per day }{ }^{1,2,4}\end{array}$}} \\
\hline & & & & \\
\hline Once daily & 252 & Referent & & $16.6^{\mathrm{a}}( \pm 0.9)$ \\
\hline Twice daily or more & 273 & $1.1( \pm 0.5)$ & 0.04 & $17.7^{\mathrm{b}}( \pm 0.9)$ \\
\hline
\end{tabular}

IR than between PR and CR (Figure 5). A recent study also observed that IR has greater influence on PR than CR (Ferguson and Skidmore, 2013).

The PR, IR, and CR were used as measures to evaluate the reproductive performance of the herds. The use of DHIA data is convenient, but the results need to be interpreted with caution because of the risk of bias. The impossibility of validation the completeness of the available data could introduce an information bias. For example, the PR could be lower than reality because of an error in reporting pregnant cows, but could also be higher than reality because of an error in reporting the cows at risk (not pregnant). Also, the data were only available for respondents that participate in DHIA and agreed to give access to their data, which introduces the possibility of selection bias. The characteristics of all the respondents and those who gave access to their data did not differ, so we expect that bias was minimal. Moreover, both biases are more likely to influence the results toward the null.

Contrary to our hypothesis, the main reproduction management practice used was not associated with 
the annual PR, which suggests that overall herd reproductive performance does not depend primarily on the main reproduction management practice itself. However, IR was higher in herds using timed AI and combined practices compared with herds using visual estrus detection. This observation could be the result of timed AI that ensures insemination despite problems such as prolonged postpartum anovulation (Walsh et al., 2007), diminished estrus expression due to lower hormone levels associated with increased steroid catabolism, lameness, or environmental factors (Rodtian et al., 1996; Juarez et al., 2003; Lopez et al., 2004; Walker et al., 2010). On the other hand, timed AI of cows that would not have shown estrus may be associated with decreased CR (Sangsritavong et al., 2002; Sakaguchi et al., 2004; Shrestha et al., 2004). For example, the prevailing use of Ovsynch as the synchronization protocol for timed AI in our sample could have affected the conception risk because of the reduced ability of this protocol to induce ovulation in anovular cows compared with Double Ovsynch (Souza et al., 2008). Interestingly, farms that reported using presynchro-

Table 4. Linear regression models and marginal means (adjusted for multiple comparisons; Tukey-Kramer) presenting associations between herd characteristics and management practices, and annual 21-d insemination rate (IR) adjusted for confounders

\begin{tabular}{|c|c|c|c|c|}
\hline Dependent variable & No. & $\begin{array}{l}\text { Coefficient } \\
\quad( \pm \mathrm{SE})\end{array}$ & $P$-value & $\begin{array}{l}\text { IR \% } \\
( \pm \text { SE })\end{array}$ \\
\hline \multicolumn{5}{|l|}{ Model 1} \\
\hline Intercept & & $40.4( \pm 1.3)$ & $<0.01$ & \\
\hline \multicolumn{5}{|l|}{ Geographical region } \\
\hline Western provinces & 81 & Referent & & $40.4^{\mathrm{a}}( \pm 1.3)$ \\
\hline Ontario & 206 & $3.1( \pm 1.5)$ & & $43.4^{\mathrm{b}}( \pm 0.8)$ \\
\hline Québec & 249 & $5.7( \pm 1.5)$ & & $46.1^{\mathrm{b}}( \pm 0.7)$ \\
\hline Maritimes & 12 & $1.2( \pm 3.5)$ & $<0.01$ & $41.6^{\mathrm{ab}}( \pm 3.3)$ \\
\hline \multicolumn{5}{|l|}{ Model 2} \\
\hline Intercept & & $35.8( \pm 1.6)$ & $<0.01$ & \\
\hline \multicolumn{5}{|l|}{ Herd size $^{1}$} \\
\hline$<50$ lactating cows & 211 & Referent & & $39.7^{\mathrm{a}}( \pm 1.2)$ \\
\hline 50-100 lactating cows & 221 & $3.7( \pm 1.1)$ & & $43.4^{\mathrm{b}}( \pm 1.1)$ \\
\hline$>100$ lactating cows & 112 & $6.1( \pm 1.4)$ & $<0.01$ & $45.8^{\mathrm{b}}( \pm 1.3)$ \\
\hline \multicolumn{5}{|l|}{ Model 3} \\
\hline Intercept & & $35.0( \pm 1.7)$ & $<0.01$ & \\
\hline \multicolumn{5}{|l|}{ Type of housing ${ }^{1,2}$} \\
\hline Freestall barn or bedded pack & 210 & Referent & & $43.7( \pm 1.1)$ \\
\hline Tiestall barn & 337 & $-1.6( \pm 1.3)$ & 0.24 & $42.1( \pm 1.2)$ \\
\hline \multicolumn{5}{|l|}{ Model 4} \\
\hline Intercept & & $34.6( \pm 1.7)$ & $<0.01$ & \\
\hline \multicolumn{5}{|l|}{ Main reproduction management at first $\mathrm{AI}^{1,3}$} \\
\hline Visual estrus detection & 275 & Referent & & $40.5^{\mathrm{a}}( \pm 1.0)$ \\
\hline Timed AI & 123 & $5.4( \pm 1.2)$ & & $45.9^{\mathrm{b}}( \pm 1.3)$ \\
\hline Automated activity monitoring & 52 & $2.3( \pm 1.8)$ & & $42.7^{\mathrm{ab}}( \pm 1.8)$ \\
\hline Other & 2 & $-15.0( \pm 7.9)$ & & $25.4^{\mathrm{ab}}( \pm 7.9)$ \\
\hline Combination of practices & 83 & $4.9( \pm 1.4)$ & $<0.01$ & $45.4^{\mathrm{b}}( \pm 1.4)$ \\
\hline \multicolumn{5}{|l|}{ Model 5} \\
\hline Intercept & & $37.2( \pm 2.1)$ & $<0.01$ & \\
\hline \multicolumn{5}{|l|}{ Use of presynchronization ${ }^{1,3,4}$} \\
\hline No & 450 & Referent & & $39.5^{\mathrm{a}}( \pm 1.8)$ \\
\hline Yes & 99 & $2.8( \pm 1.4)$ & 0.04 & $42.4^{\mathrm{b}}( \pm 2.2)$ \\
\hline \multicolumn{5}{|l|}{ Model 6} \\
\hline Intercept & & $31.4( \pm 1.7)$ & $<0.01$ & \\
\hline \multicolumn{5}{|l|}{ Reported voluntary period $d^{1,2,4}$} \\
\hline$\leq 60$ DIM & 418 & Referent & & $40.6^{\mathrm{a}}( \pm 1.8)$ \\
\hline$>60 \mathrm{DIM}$ & 130 & $-4.9( \pm 1.1)$ & $<0.01$ & $35.7^{\mathrm{b}}( \pm 2.0)$ \\
\hline \multicolumn{5}{|l|}{ Model 7} \\
\hline Intercept & & $34.2( \pm 1.8)$ & $<0.01$ & \\
\hline \multicolumn{5}{|l|}{ Frequency of AI per day ${ }^{1,2,4}$} \\
\hline Once daily & 252 & Referent & & $38.7^{\mathrm{a}}( \pm 1.9)$ \\
\hline Twice daily or more & 273 & $1.9( \pm 1.1)$ & 0.08 & $40.6^{\mathrm{b}}( \pm 1.9)$ \\
\hline
\end{tabular}

${ }^{\mathrm{a}, \mathrm{b}}$ Means within a column within a model with different superscripts differ $(P<0.05)$.

${ }^{1}$ Adjusted for geographical region.

${ }^{2}$ Adjusted for herd size.

${ }^{3}$ Adjusted for type of housing.

${ }^{4}$ Adjusted for main reproduction management practice at first AI. 
Table 5. Linear regression models and marginal means (adjusted for multiple comparisons; Tukey-Kramer) presenting associations between herd characteristics and management practices, and conception risk (CR)

\begin{tabular}{|c|c|c|c|c|}
\hline Dependent variable & No. & $\begin{array}{l}\text { Coefficient } \\
\quad( \pm \mathrm{SE})\end{array}$ & $P$-value & $\begin{array}{l}\mathrm{CR} \% \\
( \pm \mathrm{SE})\end{array}$ \\
\hline \multicolumn{5}{|l|}{ Model 1} \\
\hline Intercept & & $44.7( \pm 1.0)$ & $<0.01$ & \\
\hline \multicolumn{5}{|l|}{ Geographical region } \\
\hline Western provinces & 81 & Referent & & $44.7^{\mathrm{a}}( \pm 1.0)$ \\
\hline Ontario & 206 & $-5.0( \pm 1.1)$ & & $39.7^{\mathrm{b}}( \pm 0.6)$ \\
\hline Québec & 249 & $-4.9( \pm 1.1)$ & & $39.7^{\mathrm{b}}( \pm 0.6)$ \\
\hline Maritimes & 12 & $-4.3( \pm 2.7)$ & $<0.01$ & $40.3^{\mathrm{ab}}( \pm 2.5)$ \\
\hline \multicolumn{5}{|l|}{ Model 2} \\
\hline Intercept & & $46.7( \pm 1.2)$ & $<0.01$ & \\
\hline \multicolumn{5}{|l|}{ Herd size $^{1}$} \\
\hline$<50$ lactating cows & 211 & Referent & & $42.7^{\mathrm{a}}( \pm 0.9)$ \\
\hline 50-100 lactating cows & 221 & $-2.5( \pm 0.9)$ & & $40.2^{\mathrm{b}}( \pm 0.8)$ \\
\hline$>100$ lactating cows & 112 & $-2.0( \pm 1.1)$ & 0.01 & $40.7^{\mathrm{b}}( \pm 1.0)$ \\
\hline \multicolumn{5}{|l|}{ Model 3} \\
\hline Intercept & & $44.9( \pm 1.3)$ & $<0.01$ & \\
\hline \multicolumn{5}{|l|}{ Type of housing ${ }^{1,2}$} \\
\hline Freestall barn or bedded pack & 210 & Referent & & $42.7( \pm 0.8)$ \\
\hline Tiestall barn & 337 & $-3.5( \pm 1.0)$ & $<0.01$ & $39.2( \pm 0.9)$ \\
\hline \multicolumn{5}{|l|}{ Model 4} \\
\hline Intercept & & $44.3( \pm 1.3)$ & $<0.01$ & \\
\hline \multicolumn{5}{|c|}{ Main reproduction management at first $\mathrm{AI}^{1,3}$} \\
\hline Visual estrus detection & 275 & Referent & & $42.4^{\mathrm{a}}( \pm 0.8)$ \\
\hline Timed AI & 123 & $-2.8( \pm 0.9)$ & & $39.5^{\mathrm{b}}( \pm 1.0)$ \\
\hline Automated activity monitoring & 52 & $-2.5( \pm 1.4)$ & & $39.9^{\mathrm{ab}}( \pm 1.4)$ \\
\hline Other & 2 & $7.8( \pm 8.7)$ & & $50.2^{\mathrm{ab}}( \pm 8.7)$ \\
\hline Combination of practices & 83 & $-2.6( \pm 1.1)$ & 0.01 & $39.7^{\mathrm{ab}}( \pm 1.0)$ \\
\hline \multicolumn{5}{|l|}{ Model 5} \\
\hline Intercept & & $44.0( \pm 1.7)$ & $<0.01$ & \\
\hline \multicolumn{5}{|l|}{ Use of presynchronization ${ }^{1,3,4}$} \\
\hline No & 450 & Referent & & $42.4^{\mathrm{a}}( \pm 1.9)$ \\
\hline Yes & 99 & $-0.3( \pm 1.1)$ & 0.77 & $42.1^{\mathrm{b}}( \pm 2.1)$ \\
\hline \multicolumn{5}{|l|}{ Model 6} \\
\hline Intercept & & $47.9( \pm 1.4)$ & $<0.01$ & \\
\hline \multicolumn{5}{|l|}{ Reported voluntary period ${ }^{1,2,4}$} \\
\hline$\leq 60 \mathrm{DIM}$ & 418 & Referent & & $43.0( \pm 1.9)$ \\
\hline$>60$ DIM & 130 & $0.6( \pm 0.9)$ & 0.51 & $43.6( \pm 2.0)$ \\
\hline \multicolumn{5}{|l|}{ Model 7} \\
\hline Intercept & & $48.3( \pm 1.4)$ & $<0.01$ & \\
\hline \multicolumn{5}{|l|}{ Frequency of AI per day ${ }^{1,2,4}$} \\
\hline Once daily & 252 & Referent & & $42.7( \pm 1.9)$ \\
\hline Twice daily or more & 273 & $0.9( \pm 0.8)$ & 0.30 & $43.6( \pm 1.9)$ \\
\hline
\end{tabular}

a,b Means within a column within a model with different superscripts differ $(P<0.05)$.

${ }^{1}$ Adjusted for geographical region.

${ }^{2}$ Adjusted for herd size.

${ }^{3}$ Adjusted for type of housing.

${ }^{4}$ Adjusted for main reproduction management practice at first AI.

nization had higher PR and IR, but not higher CR. This finding could be explained by the fact that farmers using presynchronization inseminated cows within a fixed period postpartum, which results in better IR and potentially PR. Considering superior performance of modified synchronization programs (Souza et al., 2008; Herlihy et al., 2012), it is surprising that their use was not associated with an increase CR. This outcome can probably be explained by the lack of details on the type of presynchronization used on farms. The proportion of cows inseminated following presynchronization, the type of presynchronization (e.g., Double Ovsynch,
G6G), and compliance to the programs likely influence performance, but we were unable to assess those details through the questionnaire.

Even though the main reproduction management practice was not associated with $\mathrm{PR}$, other reproduction management choices and practices such as the length of the VWP and the frequency of AI per day were. As calculated here with a fixed VWP applied to all herds, a shorter VWP increases the IR and consequently the PR. For the number of AI per day, the explanation is less clear. Insemination twice versus once per day would be expected to better optimize the timing of 
insemination (Dransfield et al., 1998; Stevenson et al., 2014) and so increase CR; however, our data showed a positive association with IR but not CR (Tables 4 and 5), which might suggest an underlying component of management that was not measured by the questionnaire.

The reproductive performance indices seemed to be well understood and used by half the respondents (Figure 3), but some extreme differences were observed between reported indices and those obtained from DHIA. It was surprising to find that a high proportion of respondents were not aware of these indices on their farm because these are accepted to be the best available measures of reproductive performance (LeBlanc, 2005).

\section{CONCLUSIONS}

The present study described the diversity of the Canadian dairy farms and their reproduction management practices. Multiple reproduction management practices were used on most farms, to different extents, leading to a wide variety of approaches and methods. To evaluate the association between reproductive performance and different management practices, farms were categorized using their characteristics and their management strategies. Farm characteristics such as region, housing, and herd size as well as reported VWP and frequency of insemination per day were associated with higher IR and higher PR. Even though higher IR was observed in farms using timed AI or combined practices as the main reproduction management practice, it did not reflect sufficiently on the PR to support one approach resulting in better reproductive performance than another. This outcome supports the notion that other characteristics and management practices influence performance and likely interact with the reproduction management practices used on farm.

\section{ACKNOWLEDGMENTS}

This project was funded by the Dairy Research Cluster Initiative [Dairy Farmers of Canada (Ottawa, Canada), Agriculture and Agri-Food Canada (Ottawa, Canada), the Canadian Dairy Network (Guelph, Canada), and the Canadian Dairy Commission (Ottawa, Canada)]. We thank Canwest DHI (Guelph, Canada) and Valacta (Sainte-Anne-de-Bellevue, Canada) for their support, and we appreciate the participation of all farmers in the survey. We are also grateful to Jocelyn Dubuc (Faculté de Médecine Vétérinaire, Saint-Hyacinthe, Canada) for his help developing the questionnaire, Rebecca Vandormael (Bureau Vétérinaire de l'Islet, Saint-Jean-Port-Joli, Canada) for her role in the translation process, and
Benjamin Potvin (Ontario Veterinary College, Guelph, Canada) for entering the questionnaire data.

\section{REFERENCES}

Canadian Dairy Information Center. 2014. Overview of the Canadian dairy industry at the farm. Accessed Jun. 5, 2014. http://dairyinfo. gc.ca/index_e.php?s1 $=$ dff-fcil\&s2 $=$ farm-ferme\&s $3=$ nb.

Caraviello, D. Z., K. A. Weigel, M. Craven, D. Gianola, N. B. Cook, K. V. Nordlund, P. M. Fricke, and M. C. Wiltbank. 2006a. Analysis of reproductive performance of lactating cows on large dairy farms using machine learning algorithms. J. Dairy Sci. 89:4703-4722. http://dx.doi.org/10.3168/jds.S0022-0302(06)72521-8.

Caraviello, D. Z., K. A. Weigel, P. M. Fricke, M. C. Wiltbank, M. J. Florent, N. B. Cook, K. V. Nordlund, N. R. Zwald, and C. L. Rawson. 2006b. Survey of management practices on reproductive performance of dairy cattle on large US commercial farms. J. Dairy Sci. 89:4723-4735. http://dx.doi.org/10.3168/jds.S00220302(06) $72522-\mathrm{X}$

Dillman, D. A., J. D. Smyth, and L. M. Christian. 2008. Internet, Mail, and Mixed-Mode Surveys: The Tailored Design Method. 3rd ed. John Wiley \& Sons, Hoboken, NJ.

Dohoo, I. R., S. W. Martin, and H. Stryhn. 2009. Veterinary Epidemiologic Research. 2nd ed. VER, Inc., Charlottetown, PE, Canada.

Dolecheck, K. A., W. J. Silvia, G. Heersche, C. L. Wood, K. J. McQuerry, and J. M. Bewley. 2016. A comparison of timed artificial insemination and automated activity monitoring with hormone intervention in 3 commercial dairy herds. J. Dairy Sci. 99:1506-1514. http://dx.doi.org/10.3168/jds.2015-9914.

Dransfield, M. B., R. L. Nebel, R. E. Pearson, and L. D. Warnick. 1998. Timing of insemination for dairy cows identified in estrus by a radiotelemetric estrus detection system. J. Dairy Sci. 81:18741882. http://dx.doi.org/10.3168/jds.S0022-0302(98)75758-3.

Dufour, S., H. W. Barkema, L. DesCôteaux, T. J. DeVries, I. R. Dohoo, K. Reyher, J. P. Roy, and D. T. Scholl. 2010. Development and validation of a bilingual questionnaire for measuring udder health related management practices on dairy farms. Prev. Vet. Med. 95:74-85. http://dx.doi.org/10.1016/j.prevetmed.2010.02.018.

Ferguson, J. D., and A. Skidmore. 2013. Reproductive performance in a select sample of dairy herds. J. Dairy Sci. 96:1269-1289. http:// dx.doi.org/10.3168/jds.2012-5805.

Foote, R. H. 1975. Estrus detection and estrus detection aids. J. Dairy Sci. 58:248-256. http://dx.doi.org/10.3168/jds.S00220302(75)84555-3.

Fricke, P. M., J. O. Giordano, A. Valenza, G. Lopes, M. C. Amundson, and P. D. Carvalho. 2014. Reproductive performance of lactating dairy cows managed for first service using timed artificial insemination with or without detection of estrus using an activity-monitoring system. J. Dairy Sci. 97:2771-2781. http://dx.doi. org/10.3168/jds.2013-7366.

Herlihy, M. M., J. O. Giordano, A. H. Souza, H. Ayres, R. M. Ferreira, A. Keskin, A. B. Nascimento, J. N. Guenther, J. M. Gaska, S. J. Kacuba, M. A. Crowe, S. T. Butler, and M. C. Wiltbank. 2012. Presynchronization with Double-Ovsynch improves fertility at first postpartum artificial insemination in lactating dairy cows. J. Dairy Sci. 95:7003-7014. http://dx.doi.org/10.3168/jds.2011-5260.

Juarez, S. T., P. H. Robinson, E. J. DePeters, and E. O. Price. 2003. Impact of lameness on behavior and productivity of lactating Holstein cows. Appl. Anim. Behav. Sci. 83:1-14. http://dx.doi. org/10.1016/S0168-1591(03)00107-2.

LeBlanc, S. 2005. Overall reproductive performance of Canadian dairy cows: Challenges we are facing. Pages 137-157 in Advances in Dairy Technology: Proc. of the Western Canadian Dairy Semin. 17. University of Alberta, Faculty of Extension, Edmonton.

Lopez, H., L. D. Satter, and M. C. Wiltbank. 2004. Relationship between level of milk production and estrous behavior of lactating dairy cows. Anim. Reprod. Sci. 81:209-223. http://dx.doi. org/10.1016/j.anireprosci.2003.10.009. 
Neves, R. C., and S. J. LeBlanc. 2015. Reproductive management practices and performance of Canadian dairy herds using automated activity-monitoring systems. J. Dairy Sci. 98:2801-2811. http://dx.doi.org/10.3168/jds.2014-8221.

Neves, R. C., K. E. Leslie, J. S. Walton, and S. J. Leblanc. 2012. Reproductive performance with an automated activity monitoring system versus a synchronized breeding program. J. Dairy Sci. 95:5683-5693. http://dx.doi.org/10.3168/jds.2011-5264.

Norman, H. D., J. R. Wright, S. M. Hubbard, R. H. Miller, and J. L. Hutchison. 2009. Reproductive status of Holstein and Jersey cows in the United States. J. Dairy Sci. 92:3517-3528. http://dx.doi. org/10.3168/jds.2008-1768.

Pigott, T. D. 2001. A review of methods for missing data. Educ. Res. Eval. 7:353-383. http://dx.doi.org/10.1076/edre.7.4.353.8937.

Rodtian, P., G. King, S. Subrod, and P. Pongpiachan. 1996. Oestrous behaviour of Holstein cows during cooler and hotter tropical seasons. Anim. Reprod. Sci. 45:47-58. http://dx.doi.org/10.1016/ S0378-4320(96)01576-X.

Sakaguchi, M., Y. Sasamoto, T. Suzuki, Y. Takahashi, and Y. Yamada. 2004. Postpartum ovarian follicular dynamics and estrous activity in lactating dairy cows. J. Dairy Sci. 87:2114-2121. http:// dx.doi.org/10.3168/jds.S0022-0302(04)70030-2.

Sangsritavong, S., D. K. Combs, R. Sartori, L. E. Armentano, and M. C. Wiltbank. 2002. High feed intake increases liver blood flow and metabolism of progesterone and estradiol- $17 \beta$ in dairy cattle. J. Dairy Sci. 85:2831-2842. http://dx.doi.org/10.3168/jds.S00220302(02)74370-1.

Schefers, J. M., K. A. Weigel, C. L. Rawson, N. R. Zwald, and N. B. Cook. 2010. Management practices associated with conception rate and service rate of lactating Holstein cows in large, commercial dairy herds. J. Dairy Sci. 93:1459-1467. http://dx.doi. org/10.3168/jds.2009-2015.

Scholl, D. T., P. Dobbelaar, A. Brand, F. Brouwer, and M. Maas. 1992. Standardized protocol to develop dairy farm management questionnaires for observational studies. J. Dairy Sci. 75:615-623. http://dx.doi.org/10.3168/jds.S0022-0302(92)77799-6.

Senger, P. L. 1994. The estrus detection problem: New concepts, technologies, and possibilities. J. Dairy Sci. 77:2745-2753. http:// dx.doi.org/10.3168/jds.S0022-0302(94)77217-9.

Shrestha, H. K., T. Nakao, T. Higaki, T. Suzuki, and M. Akita. 2004. Resumption of postpartum ovarian cyclicity in high-producing Holstein cows. Theriogenology 61:637-649. http://dx.doi. org/10.1111/j.1439-0531.2008.01210.x.

Souza, A. H., H. Ayres, R. M. Ferreira, and M. C. Wiltbank. 2008. A new presynchronization system (Double-Ovsynch) increases fertility at first postpartum timed AI in lactating dairy cows. Theriogenology 70:208-215. http://dx.doi.org/10.1016/j. theriogenology.2008.03.014.

Stevenson, J. S., S. L. Hill, R. L. Nebel, and J. M. DeJarnette. 2014. Ovulation timing and conception risk after automated activity monitoring in lactating dairy cows. J. Dairy Sci. 97:4296-4308. http://dx.doi.org/10.3168/jds.2013-7873.

Van Eerdenburg, F. J., H. S. Loeffler, and J. H. van Vliet. 1996. Detection of oestrus in dairy cows: A new approach to an old problem. Vet. Q. 18:52-54. http://dx.doi.org/10.1080/01652176.1996.96946 15.

Walker, S. L., R. F. Smith, D. N. Jones, J. E. Routly, M. J. Morris, and H. Dobson. 2010. The effect of a chronic stressor, lameness, on detailed sexual behaviour and hormonal profiles in milk and plasma of dairy cattle. Reprod. Domest. Anim. 45:109-117. http:// dx.doi.org/10.1111/j.1439-0531.2008.01263.x.

Walsh, R. B., D. F. Kelton, T. F. Duffield, K. E. Leslie, J. S. Walton, and S. J. LeBlanc. 2007. Prevalence and risk factors for postpartum anovulatory condition in dairy cows. J. Dairy Sci. 90:315-324. http://dx.doi.org/10.3168/jds.S0022-0302(07)72632-2. 